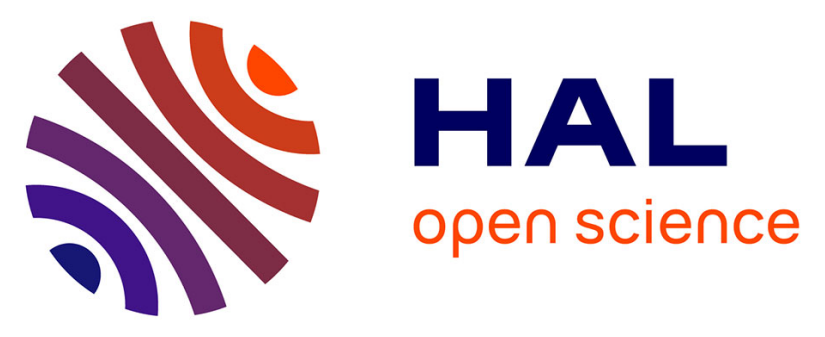

\title{
Constitutional mismatch repair deficiency as a differential diagnosis of neurofibromatosis type 1: consensus suggestions for testing a child without malignancy
}

Manon Suerink, Tim Ripperger, Ludwine Messiaen, Fred Menko, Franck Bourdeaut, Chrystelle Colas, Marjolijn Jongmans, Yael Goldberg, Maartje Nielsen, Martine Muleris, et al.

\section{- To cite this version:}

Manon Suerink, Tim Ripperger, Ludwine Messiaen, Fred Menko, Franck Bourdeaut, et al.. Constitutional mismatch repair deficiency as a differential diagnosis of neurofibromatosis type 1: consensus suggestions for testing a child without malignancy. Journal of Medical Genetics, 2019, 56 (2), pp.53-62. 10.1136/jmedgenet-2018-105664 . hal-02331880

\author{
HAL Id: hal-02331880 \\ https://hal.science/hal-02331880
}

Submitted on 24 Oct 2019

HAL is a multi-disciplinary open access archive for the deposit and dissemination of scientific research documents, whether they are published or not. The documents may come from teaching and research institutions in France or abroad, or from public or private research centers.
L'archive ouverte pluridisciplinaire HAL, est destinée au dépôt et à la diffusion de documents scientifiques de niveau recherche, publiés ou non, émanant des établissements d'enseignement et de recherche français ou étrangers, des laboratoires publics ou privés. 


\section{Constitutional mismatch repair deficiency as a differential diagnosis of neurofibromatosis type 1: consensus suggestions for testing a child without malignancy}

Manon Suerink ${ }^{1}$, Tim Ripperger ${ }^{2}$, Ludwine Messiaen ${ }^{3}$, Fred Menko ${ }^{4}$, Franck Bourdeaut ${ }^{5}$, Chrystelle Colas $^{6,7}$, Marjolijn Jongmans ${ }^{8,9}$, Yael Goldberg ${ }^{10}$, Maartje Nielsen ${ }^{1}$, Martine Muleris ${ }^{7}$, Mariëtte van Kouwen $^{11}$, Irene Slavc ${ }^{12}$, Christian Kratz ${ }^{13}$, Hans Vasen ${ }^{14}$, Laurence Brugières ${ }^{15}$, Eric Legius ${ }^{16}$, Katharina Wimmer $^{17 *}$

1. Department of Clinical Genetics, Leiden University Medical Centre, Leiden, the Netherlands

2. Department of Human Genetics, Hannover Medical School, Hannover, Germany

3. Department of Genetics, University of Alabama at Birmingham, Birmingham, AL 35294, USA.

4. Family Cancer Clinic, Antoni van Leeuwenhoek Hospital and The Netherlands Cancer Institute, Amsterdam, The Netherlands

5. Département d'Oncologie Pédiatrique et d'Adolescents Jeunes Adultes, Institut Curie, Paris, France

6. Department of Genetics, Institut Curie, Paris Sciences Lettres Research University, Paris, France

7. Sorbonne Universités, UPMC Univ Paris 06, INSERM, CNRS, Centre de Recherche Saint-Antoine (CRSA), F75012, Paris, France

8. Princess Máxima Center for Pediatric Oncology, Utrecht, The Netherlands

9. Department of Genetics, University Medical Center Utrecht, Utrecht, The Netherlands

10. Recanati Genetics Institute, Beilinson Hospital, Rabin Medical Center, Petach Tikva, Israel

11. Department of Gastroenterology and Hepatology, Radboud University Medical Center Nijmegen, Nijmegen, The Netherlands

12. Department of Pediatrics, Medical University of Vienna, Vienna, Austria.

13. Pediatric Hematology and Oncology, Hannover Medical School, Hannover, Germany

14. Department of Gastroenterology and Hepatology, Leiden University Medical Centre, Leiden, The Netherlands

15. Children and Adolescent Oncology Department, Gustave Roussy Cancer Campus, Villejuif, France

16. Department of Human Genetics, University Hospital Leuven and KU Leuven, Leuven, Belgium

17. Division of Human Genetics, Medical University Innsbruck, Innsbruck, Austria

*corresponding author: Katharina Wimmer, PhD, Division of Human Genetics, Medical University Innsbruck, Peter-MayrStraße 1, 6020 Innsbruck, Austria. Tel.: +43512 9003 70513; fax: +43512 9003 73510; e-mail: katharina.wimmer@i$\underline{\text { med.ac.at }}$

Word count: 4790 


\begin{abstract}
Constitutional mismatch repair deficiency (CMMRD) is a rare, autosomal recessively inherited cancer predisposition syndrome caused by biallelic germline mutations in one of four mismatch repair genes (MLH1, MSH2, MSH6, and PMS2). In addition to a very high tumour risk, the CMMRD phenotype is often characterized by the presence of signs reminiscent of neurofibromatosis type 1 (NF1), mainly in the form of multiple café-au-lait macules (CALMs). These, as well as other nonmalignant features, are important diagnostic signs of CMMRD in a cancer patient. Conversely, CMMRD is also a potential differential diagnosis in an otherwise healthy child with signs reminiscent of NF1/Legius syndrome without a detectable underlying NF1/SPRED1 germline mutation, as exemplified by a recently described case of a six-year-old girl with multiple CALMs, the offspring of consanguineous parents without signs of NF1, who was diagnosed with CMMRD. The European consortium Care for CMMRD (C4CMMRD) has now reviewed the expected benefits as well as the potential harm of CMMRD counselling and testing in this setting, for both the index patient and his/her at-risk relatives. Assuming that, in the absence of additional indicative features, CMMRD is rare in these patients, existing CMMRD diagnostic criteria for cancer patients were adapted to provide a consensus guideline on CMMRD testing in a child without a malignancy. Counselling and testing strategies that serve to minimize the potential harm of testing are discussed. Evaluation of this guideline by careful monitoring of children and by data sharing among physicians is recommended.
\end{abstract}

Keywords Genetic screening/counselling, Clinical genetics, Paediatric oncology 


\section{INTRODUCTION}

Constitutional mismatch repair deficiency (CMMRD, MIM \#276300) is a rare, autosomal-recessively inherited cancer predisposition syndrome caused by biallelic germline mutations in one of four mismatch repair (MMR) genes (MLH1, MIM *120436; MSH2, MIM *609309; MSH6, MIM *600678; PMS2, MIM *600259). CMMRD was first described in 1999 in children of consanguineous parents in Lynch syndrome families. ${ }^{12}$ These children, carrying homozygous MLH1 mutations, developed early onset tumours and presented with a phenotype reminiscent of neurofibromatosis type 1 (NF1) mainly in the form of multiple café-au-lait macules (CALMs). Since these first reports, well over 200 cancer patients with CMMRD have been described. Through these reports and establishment of initiatives, such as the European consortium 'Care for CMMRD' (C4CMMRD), the international biallelic mismatch repair deficiency (BMMRD) consortium and the European Reference Network for rare genetic tumour risk syndromes (ERN-GENTURIS), awareness of CMMRD and our understanding of the phenotype, the pathophysiological mechanisms of tumour development and potential management options have increased substantially. ${ }^{3-8}$

Individuals with CMMRD are prone to develop a broad spectrum of tumours. The most common are T-cell non-Hodgkin lymphomas, high-grade gliomas, and colorectal cancers or (advanced) colorectal adenomas, but also a number of other malignancies are associated with CMMRD. ${ }^{\text {9-12 }}$ Although ascertainment bias cannot be excluded, cancer risks appear to be extremely high, as almost all reported patients are diagnosed with a malignancy and approximately $80 \%$ of patients develop their first malignancy before the age of 18 years (median age of onset 10 years). ${ }^{7} 10^{11} 13-16$ However, attenuated forms of CMMRD with a higher age of tumour onset have also been reported, which are presumably caused by hypomorphic mutations (with reduced penetrance) in at least one allele. ${ }^{17-19}$

Already from the first reports, it became clear that the CMMRD phenotype overlaps with that of NF1 and prior to the onset of CMMRD-associated malignancies, it may be indistinguishable from this condition. Multiple (>5) CALM (>0.5cm in diameter) are usually the first diagnostic sign of NF1. ${ }^{20}$ In NF1, CALMs generally already appear in the first year of life, followed by skinfold freckling which is present in most children by school age. Neurofibromas usually develop after puberty and in early adulthood. ${ }^{20}$ In the past, the majority of NF1 diagnoses were based on clinical criteria from the National Institutes of Health (NIH). ${ }^{21}$ However, in young children who have a de novo NF1 mutation (accounting for almost $50 \%$ of NF1 index cases) the NIH criteria are often not fulfilled. Therefore, many NF1 clinics and paediatricians aim for early diagnosis in children through genetic testing, made possible by the improved sensitivity of NF1 mutation analysis protocols. ${ }^{22} 23$

The most important differential diagnoses of NF1 in children with multiple CALMs are mosaic NF1 
and Legius syndrome. ${ }^{2425}$ From the mutation detection rates in familial and sporadic individuals fulfilling NF1 diagnostic criteria $\left(95 \%\right.$ vs. $\left.85 \%{ }^{26}\right)$ it can be deduced that at least $10 \%$ of sporadic NF1 cases have mosaic NF1 caused by post-zygotic NF1 mutations that are undetectable in blood lymphocytes. Mosaic NF1 may present as segmental NF1, with NF1 features confined to one part of the body or as a more generalized form that may be indistinguishable from (mild forms) of NF1 due to a germline mutation. ${ }^{25}$ Legius syndrome (MIM \#611431), characterized by CALMs and freckling but absence of other diagnostic NF1 features, is caused by germline mutations in SPRED1 (MIM *609291). ${ }^{24}$ About $2.4 \%$ of sporadic patients with multiple (>5) CALMs with or without freckling, and in whom no NF1 mutation can be identified, have Legius syndrome. ${ }^{26}$ Other potential differential diagnoses of NF1 include Noonan syndrome, Noonan syndrome with multiple lentigines (previously referred to as LEOPARD syndrome), neurofibromatosis type 2 (NF2), Piebald trait and McCuneAlbright syndrome. ${ }^{27}$ However, the latter syndromes are often accompanied by other clinical features that can help in differentiating between syndromes.

Since CMMRD patients with >5 CALMs and other NF1 signs have been described, it is unsurprising that CMMRD patients occasionally receive an initial clinical diagnosis of NF1 before receiving the correct diagnosis. ${ }^{122829}$ Although not all CMMRD patients have sufficient CALMs to meet the NF1 diagnostic criterion of $>5$ CALMs and some reports emphasize that CALMs in CMMRD patients often differ from the typical uniformly pigmented and smooth-bordered CALMs associated with NF1, ${ }^{30-33}$ the majority of CMMRD patients have some hyperpigmented macules reminiscent of NF1-associated CALMs. ${ }^{34}$ Indeed, Durno and colleagues reported CALMs/hyperpigmented macules in 33 of 34 (97\%) CMMRD patients described by the international BMMRD consortium, ${ }^{10}$ and CALMs are present in at least 57 of 76 (75\%) patients registered in the C4CMMRD consortium database. The number of CALMs (diameter $>1 \mathrm{~cm}$ ) is known for 35 cases in the latter database, and more than five CALMs $>1$ $\mathrm{cm}$ were found in 26 of 35 (75\%) patients (at ages ranging from 0.9-21 years) suggesting that about half of all CMMRD patients fulfil at least one NIH criterion of NF1 (i.e. >5 CALMs).

Awareness that CALMs and occasionally other NF1 signs may be present in a child with CMMRD prior to tumour onset leads to the conclusion that CMMRD is a legitimate differential diagnosis in healthy children with CALMs (with or without other clinical signs of NF1/Legius syndrome) when no causative NF1 or SPRED1 mutation is identified, and no signs of NF1 are found in the parents. Although we can reasonably assume that CMMRD is rare in these patients if the parents are unrelated (see below Estimated frequency of CMMRD as a differential diagnosis to NF1), a six-yearold child of consanguineous parents with $>5$ CALMs and no cancer was recently diagnosed with CMMRD. $^{28}$ In this situation, a diagnosis of CMMRD may provide an opportunity for cancer 
surveillance of a highly penetrant childhood cancer syndrome prior to onset of the first malignancy. It will also allow predictive genetic testing and surveillance in relatives at risk for both CMMRD and Lynch syndrome and may impact family planning. However, it is also important to consider the potential harm associated with CMMRD counselling and testing in this setting, and any harm should be outweighed by expected benefits for both the index patient and his/her at-risk relatives. Therefore, physicians and geneticists have begun to discuss if and when to counsel and test for CMMRD in suspected NF1 patients. ${ }^{35}$

The C4CMMRD consortium, an interdisciplinary team of international experts in the field, has formulated and published diagnostic criteria for the clinical suspicion of CMMRD in cancer patients, ${ }^{7}$ in addition to surveillance guidelines. ${ }^{6}$ At the most recent workshop in Brussels $\left(26^{\text {th }}\right.$ of September 2017), the issue of when to test children without malignancy for CMMRD was addressed. The outcome of that discussion will be presented here. We propose the adaptation of existing diagnostic criteria to serve as a guideline as to when to consider CMMRD counselling and testing as differential diagnosis to NF1 in healthy individuals.

\section{ESTIMATED FREQUENCY OF CMMRD AS A DIFFERENTIAL DIAGNOSIS OF NF1}

The frequency of CMMRD in children suspected to have NF1 or Legius syndrome, but without a causative NF1 or SPRED1 mutation and no overt malignancy, is currently unknown. Since knowledge of disease frequency would help in weighing the possible benefits and harm associated with counselling and genetic testing, in the following section we attempt to roughly estimate the frequency.

The incidence of CMMRD in the general population depends on the carrier frequency of MMR mutations. The most recent empiric estimation, based on a large North American/Australian registry, calculated carrier frequencies of 1 in 1,946 for $M L H 1,1$ in 2,841 for MSH2, 1 in 758 for MSH6, and 1 in 714 for PMS2 mutations. ${ }^{36}$ Based on these frequencies, CMMRD incidence was calculated to be about 1:1,000,000 children of unrelated parents (Figure 1). The incidence will be substantially higher in populations with founder MMR mutations and in children of consanguineous parents. ${ }^{15} 3738$

NF1 is much more common, with an estimated incidence of around 1:2,000-1:3,000..$^{39-41}$ Almost half of patients with NF1 are de novo cases. ${ }^{39}$ To estimate the frequency of suspected NF1 or Legius syndrome patients without an NF1 or SPRED1 mutation who are actually affected by CMMRD, we took a number of factors into account. In a study using highly sensitive and comprehensive mutation analysis protocols, with mutation detection rates of $96 \%$ in familial NF1 patients, NF1/SPRED1 mutations were identified in 56.4\% (764/1354; 751 NF1 and 13 SPRED1 mutations) of suspected 
sporadic NF1 patients with $>5$ CALMs. ${ }^{26}$ Therefore, based on the incidence of de novo NF1 of 1:6,000 new-borns and an NF1/SPRED1 mutation detection rate of $56.4 \%$ in patients with $>5$ CALMs with or without other signs of NF1, we assume that there are 129 patients with $>5$ CALMs and no NF1/SPRED1 mutation in a population of 1 million individuals (Figure 1). Combining this estimate with the estimated frequency of CMMRD, and assuming that half of all CMMRD patients present as suspected NF1 patients prior to cancer development, we obtain a figure of one CMMRD patient among 258 suspected NF1 children without an NF1/SPRED1 mutation (i.e. $0.4 \%)$ (Figure 1). Given this low estimated frequency, a priori chances of diagnosing CMMRD in this group are low.

\section{POTENTIAL BENEFITS AND HARM OF CMMRD COUNSELLING AND TESTING IN A ‘HEALTHY’ CHILD}

Several factors need to be taken into account when considering CMMRD diagnostics in a child without a (personal history of) malignancy (Table 1).

Table 1 Overview of the potential benefits and harms of CMMRD counselling and testing in a suspected sporadic NF1/Legius syndrome child without malignancy and negative outcome of NF1/ SPRED1 germline mutation analysis.

\section{Potential benefits}

- Opportunity to begin surveillance before cancer development

- Parents can be informed of the recurrence risk in a sibling/future child

- Lynch syndrome can be diagnosed in family members and surveillance initiated

\section{Potential harms}

- Risk of diagnosing Lynch syndrome in a minor

- $\quad$ Risks associated with intensive surveillance while efficacy has not yet been evaluated in a large cohort and attenuated forms of CMMRD exist

- Risk of identifying a VUS, resulting in management dilemmas and potentially inducing anxiety

Abbreviations: CMMRD, constitutional mismatch repair deficiency. VUS, variant of unknown significance.

\section{Benefits and their limitations}

i) One of the most important benefits of an early CMMRD diagnosis is the possibility to begin surveillance before cancer development and, consequently, potentially detect cancer at an early stage with better treatment options. With regards to colorectal cancer risk, there is even the opportunity to prevent cancer by removal of intestinal polyps prior to malignant transformation, and existing recommendations for CMMRD surveillance provide clinicians with guidance regarding screening programs. ${ }^{356}$ All available guidelines recommend brain MRI, colonoscopies and video capsule endoscopy (VCE) from a young age, as well as gynaecological and urinary tract analysis from age 10 to 20 years. In addition, whole body $\mathrm{MRI}^{5}$ and preventive measures such as aspirin intake and/or vaccination with neoantigens ${ }^{42} 43$ are possible modalities that may have a role in CMMRD 
management. Preliminary analyses in a small series of patients showed promising results for surveillance measures. ${ }^{44}$ Nevertheless, all recommended programs are intensive and burdensome and evaluation of the outcome of surveillance protocols in larger studies is yet to be published. Furthermore, when CMMRD is diagnosed in a predictive setting with regard to cancer development, it should be kept in mind that attenuated forms of CMMRD show tumour onset only by the end of the second or in the third decade of life, ${ }^{17-19}{ }^{45}$ and that no evaluated models are available to accurately estimate penetrance of novel MMR mutations or new combinations of mutations. Hence, it is currently unclear whether a less stringent surveillance program might be sufficient for a subgroup of patients. Despite these reservations, as sufficient evidence points to an overall high cancer risk, the application of intensive, carefully considered screening recommendations to individuals proven to have CMMRD is justified.

ii) Another advantage of early diagnosis is the possibility to counsel parents regarding the $25 \%$ probability that siblings and subsequent children will also be affected, and to discuss the option of prenatal or preimplantation genetic diagnostics while parents are still in the process of family planning. Once again however, informed decision making is complicated by the fact that current estimates of cancer risk are subject to ascertainment bias and individual cancer risks are difficult to predict.

\section{Potential harms}

i) Following genetic counselling for CMMRD as a differential diagnosis, parents and children may experience anxiety during genetic testing until the diagnosis is largely excluded. Depending on the diagnostic strategy and performance of the laboratory, this may take several weeks or even months. Moreover, the testing strategy chosen by the laboratory will impact the predictive value of a negative test result (i.e. the residual risk in the case of a negative test, see Testing strategy). This may impact on any remaining anxiety after receiving a negative result. The level of anxiety may also differ depending on the personality and the available coping strategies of the patients/parents and the attitudes of the physicians involved.

ii) Test results definitely confirming or refuting CMMRD will be helpful in the management of the patient and his/her family. However, inconclusive test results will pose a challenge for all parties involved. The most important source of inconclusive results will be variants of unknown significance (VUS) in the MMR genes. Although identification of a VUS is an inherent risk of genetic diagnostics, it is important to minimize the number of VUS and the dilemma with regard to diagnosis and appropriate management of the patient that comes along with it. Therefore, laboratories performing CMMRD analysis in a predictive setting should be prepared to take any measure necessary to reach a 
less ambiguous classification of a VUS (C3) as either a (likely) pathogenic (C4/C5) mutation or a (likely) benign (C1/C2) variant. ${ }^{46}$ Tests assessing hallmarks of MMR deficiency in vivo or the effect of the mutation(s) on mismatch repair protein function in vitro will become important in these situations (see Testing strategy).

iii) According to Win et al., ${ }^{36}$ in the general population one in 279 children tested will be heterozygous for an MMR gene mutation. Particularly in the case of a clearly pathogenic MLH1 or MSH2 mutation, this results is the unintentional diagnosis of Lynch syndrome in a minor. Lynch syndrome mainly predisposes to adult-onset colorectal cancer and/or endometrial cancer and surveillance only begins around age 20-25. ${ }^{47} 48$ Thus the lack of clinical consequences in children, combined with their right not-to-know, and potential harm due to anxiety and other issues (e.g., potential difficulty in acquiring insurance) highlight that a diagnosis of Lynch syndrome is undesirable in a minor. ${ }^{49}$ Further considerations on this topic can be found in Bruwer et al. who offered predictive CMMRD testing to children of parents both carrying familial MLH1 mutations. ${ }^{50}$ The situation is more complex for MSH6 and even more so for PMS2. Heterozygous mutations in these genes have a 2-4 times higher prevalence, ${ }^{36}$ but a substantially lower penetrance than MLH1 and MSH2 mutations. ${ }^{19} 5152$ Hence, in an individual lacking a personal or family history of Lynch syndrome-associated cancer, it is uncertain whether the mutation-associated cancer risk is sufficient to diagnose an individual with a cancer predisposition syndrome that warrants intensive cancer surveillance. This concern also raises the question of whether identifying a mutation in an individual without family history for Lynch syndrome justifies predictive genetic testing in parents and other adult at-risk relatives.

\section{LIMITING POTENTIAL HARM ASSOCIATED WITH CMMRD COUNSELLING AND TESTING IN A CHILD WITHOUT A MALIGNANCY}

Assuming that only a small minority ( $0.4 \%)$ of all NF1/SPRED1 mutation-negative children from nonrelated parents will actually have CMMRD syndrome, it would be desirable to reduce the number of individuals/families with whom the possibility of CMMRD needs to be discussed. Therefore, strategies to pre-select children with a high probability of having CMMRD are discussed in the following section.

\section{Testing prerequisites}

Three prerequisites for considering testing for CMMRD as a differential diagnosis of NF1/Legius syndrome are defined in Table 2: (i) the presence of at least one NF1 diagnostic criterion including multiple hyperpigmented skin patches reminiscent of CALMs. The most prevalent NF1 sign present 
in a CMMRD patient is hyperpigmented skin patches reminiscent of NF1-associated CALMs and freckling. Other diagnostic NF1 features such as neurofibromas, Lisch nodules, tibial pseudarthrosis or optic pathway glioma have so far only been seen in CMMRD patients who also show CALMs. ${ }^{12} 1553$

${ }^{54}$ This suggests that CMMRD syndrome is a highly unlikely diagnosis in individuals with only isolated non-pigmentary NF1 features. (ii) NF1/SPRED1 testing was performed using highly sensitive, comprehensive mutation analysis protocols. The likelihood of identifying CMMRD is of course correlated with the sensitivity of NF1/SPRED1 mutation analysis performed (further discussed in Testing strategies). (iii) the absence of any signs of NF1 in either parent. If a parent shows any NF1 signs, even very subtle, an undetected NF1/SPRED1 mutation, which might even be present in a mosaic status in the mildly affected parent, is probably more likely. It is strongly recommended that both parents undergo a full clinical exam for presence of any (mild) features of NF1, and for this purpose a consultation with an ophthalmologist and dermatologist can be considered.

It was decided not to include an age limit in the prerequisites for testing, as in CMMRD a wide variability has been observed in the age of cancer diagnosis. ${ }^{11} 4552$ However, when evaluating a patient who meets the prerequisites it should be kept in mind that the vast majority (around $80 \%)^{10}$ ${ }^{11} 13-16$ of CMMRD patients will have developed a malignancy or intestinal adenomas by the age of eighteen. Hence, absence of a (pre-)malignancy in an older individual decreases the probability of CMMRD substantially.

\section{Pre-selection strategies}

The presence in a child of one or more additional features suggestive of CMMRD substantially increases the likelihood of this differential diagnosis. The European C4CMMRD consortium has previously defined diagnostic criteria based on features that raise suspicion of CMMRD in a cancer patient. ${ }^{7}$ By and large, these features could also be used to select children without cancer who have an increased probability of having CMMRD. Therefore, the list of additional features provided in table 2 largely overlaps with the previously defined diagnostic criteria for CMMRD in a cancer patient (for further details see ${ }^{7}$ ). 
Table 2 Selection strategy for CMMRD counselling and testing in a suspected NF1/Legius syndrome child without malignancy and negative outcome of NF1/SPRED1 germline mutation analysis.

\section{Prerequisites}

- Suspicion of NF1 due to the presence of at least one diagnostic NF1 feature ${ }^{1}$, including at least two hyperpigmented skin patches reminiscent of CALMs

- No NF1 and SPRED1 germline mutations detected using comprehensive and highly sensitive mutation analysis protocols ${ }^{2}$

- Absence of NF1 signs in both parents

\section{Additional features, at least one is required}

In the family

- Consanguineous parents

- Genetic diagnosis of Lynch syndrome in one or both of the parental families

- Sibling with signs of NF1

- A (deceased) sibling ${ }^{3}$ with any type of childhood malignancy

- One of the following carcinomas from the Lynch syndrome spectrum ${ }^{4}$ : colorectal cancer, endometrial cancer, ovarian cancer, gastric cancer, small bowel cancer, cancer of the bile duct or gall bladder, pancreatic cancer or urothelial cancer before the age of 60 in first-degree or second-degree relative

In the patient

- Atypical CALMs (irregular borders and/or pigmentation)

- Hypopigmented skin patches

- One or more pilomatricoma(s) in the patient

- Agenesis of the corpus callosum

- Non-therapy-induced cavernoma

- Multiple developmental vascular abnormalities (DVA; also known as cerebral venous angiomas) in separate regions of the brain

Abbreviations: NF1, neurofibromatosis type 1. CALMs, café-au-lait macules.

${ }^{1}$ Neurofibromatosis conference statement.(21) ${ }^{2}$ See testing strategy. ${ }^{3}$ This can be expanded to $2^{\text {nd }}$ and $3^{\text {rd }}$ degree relatives in populations with a high prevalence of founder mutations. ${ }^{4} \mathrm{M} \varnothing$ ller et al. 2017 (47)

A feature listed in the original table in ${ }^{7}$ was 'deficiency/reduced levels of $\lg G 2 / 4$ and/or $\lg A^{\prime}$ '. As a recent study on a cohort of 15 consecutive, unrelated patients was unable to show uniform or specific patterns of laboratory immunological abnormalities, ${ }^{55}$ we did not include this rather unspecific feature in table 2 .

Two features increasing the likelihood of having CMMRD and not listed in the original table by Wimmer et al. ${ }^{7}$ were added to the current table. The first one is a sibling with signs of NF1, in the absence of any NF1 signs in both parents when gonadal NF1/SPRED1 mosaicism in a parent has 
largely been excluded by mutation analysis in the children. The second is the presence of multiple developmental vascular abnormalities (DVA; also known as cerebral venous angiomas) in separate regions of the brain, which were present in 10/10 patients described by Shiran et al., ${ }^{56}$ who suggested this feature as additional non-neoplastic sign indicating CMMRD in a cancer patient.

Furthermore, a number of CMMRD patients have been reported to have atypical CALMs with irregular borders and different degrees of pigmentation. ${ }^{30-34}$ Therefore, atypical macules that might be differentiated from typical NF1-associated macules by an experienced clinician/geneticist (see also Counselling strategy and setting), are suggestive of a differential diagnosis such as CMMRD. ${ }^{30-34}$ Hence, presence of atypical CALMs is also included as an additional feature in Table 2.

Some CMMRD-associated features included in Table 2 (e.g. brain anomalies) will not be detected by routine clinical examination of a suspected NF1 patient. Since the prevalence and specificity of these features in CMMRD patients is not well studied, we do not advocate testing for these features unless clinically indicated.

A thorough family history will help in uncovering family members with Lynch syndrome-associated cancers (Table 2). When a Lynch syndrome-associated cancer is present it may be worthwhile, where possible, to analyse the tumour for signs of mismatch repair deficiency.

A thorough assessment of the family history should include also questions regarding consanguinity of the parents. The risk of having CMMRD based on the allele frequencies of MMR gene mutations ${ }^{36}$ in for example a child of first cousins is $\sim 1 / 8,849$ (using the equation $\left[p_{i} f_{I}+p_{i}^{2}\left(1-f_{I}\right)\right]+\left[p_{j} f_{I}+p_{j}^{2}(1-\right.$ $\left.\left.f_{I}\right)\right]+\left[p_{k} f_{I}+p_{k}^{2}\left(1-f_{I}\right)\right]+\left[p_{I} f_{I}+p_{l}^{2}\left(1-f_{I}\right)\right]$ where $p_{i}, p_{j}, p_{k}$ and $p_{I}$ are the allele frequencies of MLH1, MSH2, MSH6 and PMS2 mutations, respectively, and the consanguinity coefficient $f_{I}$ for first cousins = $1 / 16)^{57}$ which is about 110 -times higher than for a child with unrelated parents.

\section{Counselling strategy and setting}

Since NF1 is a relatively common and often easily recognizable syndrome for which clear management guidelines exist, many paediatricians order molecular analysis of the NF1 gene directly without involving a clinical genetics specialist. Counselling and management are more challenging for the much rarer and highly penetrant cancer predisposition syndrome CMMRD. We therefore advocate that predictive (with respect to malignancy) CMMRD testing should be ordered by a physician trained in clinical cancer genetics in a centre with specific expertise in NF1 and related disorders in a multi-disciplinary setting. 
As mentioned above, we suggest that CMMRD does not need to be discussed in all suspected NF1 cases without an identified NF1/SPRED1 mutation. Following an interdisciplinary discussion and the decision that counselling for CMMRD is indicated in a child without a malignancy, parents and their affected child, depending on his/her age, should be counselled by an experienced geneticist. To be able to make an informed decision on whether they want their child to be tested, parents should be made aware of the potential benefits, with their limitations, and of the various possible outcomes of genetic testing. Nevertheless, considering the low probability of a CMMRD diagnosis, this information should be provided in a way that minimizes risk of inducing a disproportionately high level of anxiety. If parents express the need for psychological support or more information on surveillance protocols or cancer treatment options, consultation with a psycho-oncologist or paediatric oncologist should be offered.

Specifically trained clinical geneticists/clinicians may be able to differentiate between typical NF1associated CALMs and the atypical pigmentations sometimes seen in CMMRD patients. ${ }^{30-34}$ Furthermore, he/she can decide whether another syndrome (e.g., Noonan syndrome, Noonan syndrome with multiple lentigines, NF2, Piebald trait and McCune-Albright syndrome) within the differential diagnosis of children with CALMs is more likely and should be addressed by genetic testing prior to CMMRD testing. Lastly, we advise that any centre ordering CMMRD diagnostics is able to facilitate the surveillance program, either in-house or in cooperating centres within reasonable travelling distance.

\section{Testing strategy}

A prerequisite for considering CMMRD counselling and testing as a differential diagnosis in patients suspect for NF1/Legius syndrome is the exclusion of the latter diagnoses with high certainty by absence of germline NF1/SPRED1 mutations using highly sensitive mutation analyses. The NF1 gene is large and has a highly diverse mutational spectrum, with private mutations (i.e. not reported in any other patient) identified in a significant percentage of patients ( $25 \%$; LM, personal communication). Furthermore, the NF1 mutation spectrum also includes a large proportion of unusual splice mutations that either completely elude genomic DNA (gDNA)-based mutation analysis protocols (e.g. deep intronic mutations are found in $2.5-3 \%$ of all NF1 patients) or defy ready classification as (likely) pathogenic mutations without additional transcript analysis (approximately $20 \%$ of patients have a splice mutation NOT affecting the AG/GT dinucleotides, but affect coding nucleotides, nucleotides flanking the exons but further up/downstream of the AG/GT dinucleotides or reside very deep into the introns). ${ }^{22} 5859$ This complicates the classification of novel mutations, especially in the case of silent, missense, and intronic variants. ${ }^{60}$ Currently, only comprehensive 
mutation analysis protocols that include NF1 transcript analysis as a primary or complementary assay, such as direct cDNA sequencing, ${ }^{23}$ will achieve sufficient sensitivity to exclude a germline mutation with a $96 \%$ certainty. ${ }^{26}$ Genomic DNA-based mutation analysis methods can achieve high SPRED1 mutation detection rates (RNA-based mutation analysis performed in $>900$ patients has not yet identified a SPRED1 splice mutation that escaped detection in GDNA; LM, unpublished data).

Segmental or mosaic NF1 due to a post-zygotic NF1 mutation is the most likely differential diagnosis in a child with CALMs, with or without other NF1 signs, and a negative germline NF1/SPRED1 mutation analysis. Confirming mosaic NF1 however requires identification of the same post-zygotic mutation in multiple melanocyte or Schwann cell cultures from biopsied CALMs and neurofibromas respectively. ${ }^{61}$ These labour intensive analyses require specific expertise and therefore are offered only by very few specialized laboratories worldwide. Furthermore, they require invasive procedures. Taken together, this can justify omitting these analyses in children to evaluate mosaic/segmental NF1 prior to CMMRD testing.

In principle, two CMMRD testing strategies can be pursued. The first strategy is direct mutational testing of the MMR genes. The second strategy involves a pre-assay which tests for hallmarks of CMMRD, followed by mutational testing if positive. When opting for direct mutational testing it should be kept in mind that mutation analysis of PMS2, the most commonly mutated gene in CMMRD, is challenging due to the presence of pseudogenes. ${ }^{62-65}$ Therefore, appropriate methods should be applied to circumvent potential pitfalls of PMS2 mutation analysis. ${ }^{66-72}$

An argument in favour of direct mutation analysis using gDNA-based gene panel diagnostics would be that other genes that may mimic the NF1 phenotype (see Introduction) can be analysed simultaneously. However, testing a larger number of genes inevitably increases the likelihood of identifying VUSes. Therefore, we advocate a stepwise approach, ruling out other possible differential diagnoses prior to CMMRD testing.

If a VUS is identified in one of the MMR genes, additional analyses should be performed to assist with the interpretation of the variant, such as ex vivo functional assays of the mutated gene $e^{73-79}$ and/or assays that determine the presence of MMRD in non-neoplastic tissue of the patient. The latter assays could also be used as pre-assays before or in parallel with mutation analysis. This second strategy reduces the risk of VUS identification by providing functional evidence for or against CMMRD, and at the same time increases diagnostic sensitivity by applying two complementary methods.

Microsatellite instability (MSI), defined as a change in the number of mononucleotide or dinucleotide repeats and detectable by alterations in microsatellite fragment length, ${ }^{80}$ is a well- 
established hallmark of somatic MMRD and is frequently assessed in cancer tissues during testing for Lynch syndrome. MSI is not restricted to neoplastic cells in patients with CMMRD and assays have been developed to detect low levels of MSI in leucocyte DNA of these patients. ${ }^{81}$ Although highly sensitive and specific in patients with biallelic PMS2, MLH1 and MSH2 mutations, in patients with biallelic MSH6 mutations, the currently available germline microsatellite instability (gMSI) assays regularly yield normal results. This limitation renders this gMSI assay unsuitable for pre-test selection. However this simple, fast and inexpensive assay can increase diagnostic sensitivity and accuracy by confirming the pathogenicity of PMS2, MLH1 and MSH2 VUS. ${ }^{28}$ In the near future more sensitive, simple and reliable gMSI assays may become available, which could potentially be used for pre-test selection. Recently, a highly sensitive and reliable method for the detection of low levels of MSI was developed, with potential applications in the analysis of MSI in non-neoplastic tissue of CMMRD patients. ${ }^{82}$ Another assay, which tests for MSI in EBV-immortalised lymphocytes and in parallel for cell tolerance to methylating agents (another functional consequence of CMMRD), has recently been specifically developed for CMMRD diagnosis. ${ }^{83}$ As this assay is both highly sensitive and specific it may allow a diagnosis of CMMRD to be definitively confirmed or refuted in cases where mutation analysis and other assays are inconclusive (e.g. when only one MMR gene mutation or a homozygous MMR gene VUS has been identified) ${ }^{83}{ }^{84}$ However, the assay is lengthy, labour intensive and requires expertise, making it ill-suited as a pre-test. Immunohistochemistry (IHC) to detect loss of expression of one or more MMR protein(s) in non-neoplastic tissue, such as small skin biopsies, has also been proposed as a diagnostic assay for CMMRD. ${ }^{10}{ }^{13}$ However, as taking a skin biopsy is an invasive procedure that can be unpleasant for a young child, IHC should be avoided as a pre-test. Furthermore, IHC may also be insensitive if antigenic but non-functional mutations are present. $^{84-86}$

Taken together, reliable diagnostics of CMMRD may at times be challenging. Choosing an appropriate testing strategy may depend on the facilities that are most readily available in the centre. Hopefully, more assays will become available that may facilitate simple and reliable selective pre-testing for CMMRD.

\section{CONCLUDING REMARKS}

We discussed here the potential benefits and harm (Table 1) associated with CMMRD counselling and testing in children suspected to have sporadic NF1 but without a malignancy and lacking an NF1 or SPRED1 germline mutation. After carefully considering all available literature and our own experiences, we arrived at recommendations as to when to counsel and offer CMMRD testing, which are summarized in Table 2. We also note that uncertainties exist regarding the incidence of CMMRD 
and the prevalence of CMMRD-associated features both in the general population and in unselected CMMRD patients. Clearly, more data are needed to further support our recommendations, particularly since published CMMRD cases may be biased towards a more severe phenotype. We strongly recommend that the clinical course of all CMMRD patients who are identified before cancer development is meticulously recorded and submitted to a database. Overall, we believe that with the application of the suggested counselling and testing prerequisites an acceptable balance can be achieved between adequate testing of patients at risk of CMMRD, while avoiding exposing an unnecessarily large number of children and families to any harm that might ensue from counselling and genetic testing for CMMRD.

Acknowledgements: The authors thank Medactie.com for help with editing of this paper.

Competing interests: The authors have no conflict of interests to report.

Funding: Not applicable.

Contributors: The guidelines have been discussed during a C4CMMRD workshop in Brussels on Sept. 26, 2017. All authors were involved in this discussion during the meeting and/or thereafter. The manuscript was drafted by MS and KW. All authors read and revised the manuscript with major contributions of TR, LM, FM, LB and EL. Being a member of GENTURIS, EL represented also the interests of this European Reference Network.

\section{REFERENCES}

1. Ricciardone MD, Ozcelik T, Cevher B, Ozdag H, Tuncer M, Gurgey A, Uzunalimoglu O, Cetinkaya H, Tanyeli A, Erken E, Ozturk M. Human MLH1 deficiency predisposes to hematological malignancy and neurofibromatosis type 1. Cancer Res 1999;59(2):290-3.

2. Wang $Q$, Lasset C, Desseigne F, Frappaz D, Bergeron C, Navarro C, Ruano E, Puisieux A. Neurofibromatosis and early onset of cancers in hMLH1-deficient children. Cancer Res 1999;59(2):294-7.

3. Durno C, Boland CR, Cohen S, Dominitz JA, Giardiello FM, Johnson DA, Kaltenbach T, Levin TR, Lieberman D, Robertson DJ, Rex DK. Recommendations on Surveillance and Management of Biallelic Mismatch Repair Deficiency (BMMRD) Syndrome: A Consensus Statement by the US Multi-society Task Force on Colorectal Cancer. J Pediatr Gastroenterol Nutr 2017;64(5):83643.

4. Shlien A, Campbell BB, de Borja R, Alexandrov LB, Merico D, Wedge D, Van Loo P, Tarpey PS, Coupland P, Behjati S, Pollett A, Lipman T, Heidari A, Deshmukh S, Avitzur N, Meier B, Gerstung M, Hong Y, Merino DM, Ramakrishna M, Remke M, Arnold R, Panigrahi GB, Thakkar NP, Hodel KP, Henninger EE, Goksenin AY, Bakry D, Charames GS, Druker H, LernerEllis J, Mistry M, Dvir R, Grant R, Elhasid R, Farah R, Taylor GP, Nathan PC, Alexander S, BenShachar S, Ling SC, Gallinger S, Constantini S, Dirks P, Huang A, Scherer SW, Grundy RG, Durno C, Aronson M, Gartner A, Meyn MS, Taylor MD, Pursell ZF, Pearson CE, Malkin D, Futreal PA, Stratton MR, Bouffet E, Hawkins C, Campbell PJ, Tabori U, Biallelic Mismatch Repair Deficiency C. Combined hereditary and somatic mutations of replication error repair genes result in rapid onset of ultra-hypermutated cancers. Nat Genet 2015;47(3):257-62. 
5. Tabori U, Hansford JR, Achatz MI, Kratz CP, Plon SE, Frebourg T, Brugieres L. Clinical Management and Tumor Surveillance Recommendations of Inherited Mismatch Repair Deficiency in Childhood. Clin Cancer Res 2017;23(11):e32-e37.

6. Vasen HF, Ghorbanoghli Z, Bourdeaut F, Cabaret O, Caron O, Duval A, Entz-Werle N, Goldberg Y, llencikova D, Kratz CP, Lavoine N, Loeffen J, Menko FH, Muleris M, Sebille G, Colas C, Burkhardt B, Brugieres L, Wimmer K, CMMR-D EU-CCf. Guidelines for surveillance of individuals with constitutional mismatch repair-deficiency proposed by the European Consortium "Care for CMMR-D" (C4CMMR-D). J Med Genet 2014;51(5):283-93.

7. Wimmer K, Kratz CP, Vasen HF, Caron O, Colas C, Entz-Werle N, Gerdes AM, Goldberg Y, Ilencikova D, Muleris M, Duval A, Lavoine N, Ruiz-Ponte C, Slavc I, Burkhardt B, Brugieres L, CMMRD EU-CCf. Diagnostic criteria for constitutional mismatch repair deficiency syndrome: suggestions of the European consortium 'care for CMMRD' (C4CMMRD). J Med Genet 2014;51(6):355-65.

8. Bouffet E, Larouche V, Campbell BB, Merico D, de Borja R, Aronson M, Durno C, Krueger J, Cabric V, Ramaswamy V, Zhukova N, Mason G, Farah R, Afzal S, Yalon M, Rechavi G, Magimairajan V, Walsh MF, Constantini S, Dvir R, Elhasid R, Reddy A, Osborn M, Sullivan M, Hansford J, Dodgshun A, Klauber-Demore N, Peterson L, Patel S, Lindhorst S, Atkinson J, Cohen Z, Laframboise R, Dirks P, Taylor M, Malkin D, Albrecht S, Dudley RW, Jabado N, Hawkins CE, Shlien A, Tabori U. Immune Checkpoint Inhibition for Hypermutant Glioblastoma Multiforme Resulting From Germline Biallelic Mismatch Repair Deficiency. J Clin Oncol 2016;34(19):2206-11.

9. Daou $B$, Zanello $M$, Varlet $P$, Brugieres $L$, Jabbour $P$, Caron $O$, Lavoine $N$, Dhermain $F$, Willekens $C$, Beuvon F, Malka D, Lechapt-Zalcmann E, Abi Lahoud G. An Unusual Case of Constitutional Mismatch Repair Deficiency Syndrome With Anaplastic Ganglioglioma, Colonic Adenocarcinoma, Osteosarcoma, Acute Myeloid Leukemia, and Signs of Neurofibromatosis Type 1: Case Report. Neurosurgery 2015;77(1):E145-52; discussion E52.

10. Durno CA, Sherman PM, Aronson M, Malkin D, Hawkins C, Bakry D, Bouffet E, Gallinger S, Pollett A, Campbell B, Tabori U, International BC. Phenotypic and genotypic characterisation of biallelic mismatch repair deficiency (BMMR-D) syndrome. Eur J Cancer 2015;51(8):977-83.

11. Lavoine N, Colas C, Muleris M, Bodo S, Duval A, Entz-Werle N, Coulet F, Cabaret O, Andreiuolo F, Charpy C, Sebille G, Wang Q, Lejeune S, Buisine MP, Leroux D, Couillault G, Leverger G, Fricker JP, Guimbaud R, Mathieu-Dramard M, Jedraszak G, Cohen-Hagenauer O, GuerriniRousseau L, Bourdeaut F, Grill J, Caron O, Baert-Dusermont S, Tinat J, Bougeard G, Frebourg $T$, Brugieres L. Constitutional mismatch repair deficiency syndrome: clinical description in a French cohort. J Med Genet 2015;52(11):770-8.

12. Bush L, Aronson M, Tabori U, Campbell BB, Bedgood RB, Jasperson K. Delineating a new feature of constitutional mismatch repair deficiency (CMMRD) syndrome: breast cancer. Fam Cancer 2018.

13. Bakry D, Aronson M, Durno C, Rimawi H, Farah R, Alharbi QK, Alharbi $M$, Shamvil A, Ben-Shachar S, Mistry M, Constantini S, Dvir R, Qaddoumi I, Gallinger S, Lerner-Ellis J, Pollett A, Stephens D, Kelies S, Chao E, Malkin D, Bouffet E, Hawkins C, Tabori U. Genetic and clinical determinants of constitutional mismatch repair deficiency syndrome: report from the constitutional mismatch repair deficiency consortium. Eur J Cancer 2014;50(5):987-96.

14. Aronson M, Gallinger S, Cohen Z, Cohen S, Dvir R, Elhasid R, Baris HN, Kariv R, Druker H, Chan H, Ling SC, Kortan P, Holter S, Semotiuk K, Malkin D, Farah R, Sayad A, Heald B, Kalady MF, Penney LS, Rideout AL, Rashid M, Hasadsri L, Pichurin P, Riegert-Johnson D, Campbell B, Bakry D, Al-Rimawi H, Alharbi QK, Alharbi M, Shamvil A, Tabori U, Durno C. Gastrointestinal Findings in the Largest Series of Patients With Hereditary Biallelic Mismatch Repair Deficiency Syndrome: Report from the International Consortium. Am J Gastroenterol 2016;111(2):275-84. 
15. Baris HN, Barnes-Kedar I, Toledano H, Halpern M, Hershkovitz D, Lossos A, Lerer I, Peretz T, Kariv R, Cohen S, Half EE, Magal N, Drasinover V, Wimmer K, Goldberg Y, Bercovich D, Levi Z. Constitutional Mismatch Repair Deficiency in Israel: High Proportion of Founder Mutations in MMR Genes and Consanguinity. Pediatr Blood Cancer 2016;63(3):418-27.

16. Wimmer K, Etzler J. Constitutional mismatch repair-deficiency syndrome: have we so far seen only the tip of an iceberg? Hum Genet 2008;124(2):105-22.

17. Li L, Hamel N, Baker K, McGuffin MJ, Couillard M, Gologan A, Marcus VA, Chodirker B, Chudley A, Stefanovici C, Durandy A, Hegele RA, Feng BJ, Goldgar DE, Zhu J, De Rosa M, Gruber SB, Wimmer K, Young B, Chong G, Tischkowitz MD, Foulkes WD. A homozygous PMS2 founder mutation with an attenuated constitutional mismatch repair deficiency phenotype. $J$ Med Genet 2015;52(5):348-52.

18. Rengifo-Cam W, Jasperson K, Garrido-Laguna I, Colman H, Scaife C, Samowitz W, Samadder NJ. A 30-Year-Old Man with Three Primary Malignancies: A Case of Constitutional Mismatch Repair Deficiency. ACG Case Rep J 2017;4:e34.

19. Senter L, Clendenning M, Sotamaa K, Hampel H, Green J, Potter JD, Lindblom A, Lagerstedt K, Thibodeau SN, Lindor NM, Young J, Winship I, Dowty JG, White DM, Hopper JL, Baglietto L, Jenkins MA, de la Chapelle A. The clinical phenotype of Lynch syndrome due to germ-line PMS2 mutations. Gastroenterology 2008;135(2):419-28.

20. DeBella K, Szudek J, Friedman JM. Use of the national institutes of health criteria for diagnosis of neurofibromatosis 1 in children. Pediatrics 2000;105(3 Pt 1):608-14.

21. Neurofibromatosis. Conference statement. National Institutes of Health Consensus Development Conference. Arch Neurol 1988;45(5):575-8.

22. Messiaen LM, Callens T, Mortier G, Beysen D, Vandenbroucke I, Van Roy N, Speleman F, Paepe AD. Exhaustive mutation analysis of the NF1 gene allows identification of $95 \%$ of mutations and reveals a high frequency of unusual splicing defects. Hum mutat 2000;15(6):541-55.

23. Messiaen LM, Wimmer K. Mutation analysis of the NF1 gene by CDNA-based sequencing of the coding region. In: Soares Gonçalves Cunha K, Geller M, eds. Advances in neurofibromatosis research. New York: Nova Science Publishers, Inc., 2011:89-108.

24. Brems H, Chmara M, Sahbatou M, Denayer E, Taniguchi K, Kato R, Somers R, Messiaen L, De Schepper S, Fryns JP, Cools J, Marynen P, Thomas G, Yoshimura A, Legius E. Germline loss-offunction mutations in SPRED1 cause a neurofibromatosis 1-like phenotype. Nat Genet 2007;39(9):1120-6.

25. Garcia-Romero MT, Parkin P, Lara-Corrales I. Mosaic Neurofibromatosis Type 1: A Systematic Review. Pediatr Dermatol 2016;33(1):9-17.

26. Messiaen L, Yao S, Brems H, Callens T, Sathienkijkanchai A, Denayer E, Spencer E, Arn P, BabovicVuksanovic D, Bay C, Bobele G, Cohen BH, Escobar L, Eunpu D, Grebe T, Greenstein R, Hachen R, Irons M, Kronn D, Lemire E, Leppig K, Lim C, McDonald M, Narayanan V, Pearn A, Pedersen R, Powell B, Shapiro LR, Skidmore D, Tegay D, Thiese H, Zackai EH, Vijzelaar R, Taniguchi K, Ayada T, Okamoto F, Yoshimura A, Parret A, Korf B, Legius E. Clinical and mutational spectrum of neurofibromatosis type 1-like syndrome. JAMA 2009;302(19):21118.

27. Jett K, Friedman JM. Clinical and genetic aspects of neurofibromatosis 1. Genet Med 2010;12(1):1-11.

28. Suerink M, Potjer TP, Versluijs AB, Ten Broeke SW, Tops CM, Wimmer K, Nielsen M. Constitutional mismatch repair deficiency in a healthy child: On the spot diagnosis? Clin Genet 2018;93(1):134-37.

29. Urganci N, Genc DB, Kose G, Onal Z, Vidin OO. Colorectal Cancer due to Constitutional Mismatch Repair Deficiency Mimicking Neurofibromatosis I. Pediatrics 2015;136(4):e1047-50.

30. Tan TY, Orme LM, Lynch E, Croxford MA, Dow C, Dewan PA, Lipton L. Biallelic PMS2 mutations and a distinctive childhood cancer syndrome. J Pediatr Hematol Oncol 2008;30(3):254-7. 
31. Scott RH, Homfray T, Huxter NL, Mitton SG, Nash R, Potter MN, Lancaster D, Rahman N. Familial T-cell non-Hodgkin lymphoma caused by biallelic MSH2 mutations. J Med Genet 2007;44(7):e83.

32. Kruger S, Kinzel M, Walldorf C, Gottschling S, Bier A, Tinschert S, von Stackelberg A, Henn W, Gorgens H, Boue S, Kolble K, Buttner R, Schackert HK. Homozygous PMS2 germline mutations in two families with early-onset haematological malignancy, brain tumours, HNPCC-associated tumours, and signs of neurofibromatosis type 1. Eur J Hum Genet 2008;16(1):62-72.

33. De Vos M, Hayward BE, Charlton R, Taylor GR, Glaser AW, Picton S, Cole TR, Maher ER, McKeown $\mathrm{CM}$, Mann JR, Yates JR, Baralle D, Rankin J, Bonthron DT, Sheridan E. PMS2 mutations in childhood cancer. J Natl Cancer Inst 2006;98(5):358-61.

34. Wimmer K, Rosenbaum T, Messiaen L. Connections between constitutional mismatch repair deficiency syndrome and neurofibromatosis type 1. Clin Genet 2017;91(4):507-19.

35. Evans DGR, Salvador H, Chang VY, Erez A, Voss SD, Schneider KW, Scott HS, Plon SE, Tabori U. Cancer and Central Nervous System Tumor Surveillance in Pediatric Neurofibromatosis 1. Clin Cancer Res 2017;23(12):e46-e53.

36. Win AK, Jenkins MA, Dowty JG, Antoniou AC, Lee A, Giles GG, Buchanan DD, Clendenning M, Rosty C, Ahnen DJ, Thibodeau SN, Casey G, Gallinger S, Le Marchand L, Haile RW, Potter JD, Zheng Y, Lindor NM, Newcomb PA, Hopper JL, Maclnnis RJ. Prevalence and Penetrance of Major Genes and Polygenes for Colorectal Cancer. Cancer Epidemiol Biomarkers Prev 2017;26(3):404-12.

37. Amayiri N, Tabori U, Campbell B, Bakry D, Aronson M, Durno C, Rakopoulos P, Malkin D, Qaddoumi I, Musharbash A, Swaidan M, Bouffet E, Hawkins C, Al-Hussaini M, Consortium B. High frequency of mismatch repair deficiency among pediatric high grade gliomas in Jordan. Int J Cancer 2016;138(2):380-5.

38. Ponti G, Castellsague E, Ruini C, Percesepe A, Tomasi A. Mismatch repair genes founder mutations and cancer susceptibility in Lynch syndrome. Clin Genet 2015;87(6):507-16.

39. Evans DG, Howard E, Giblin C, Clancy T, Spencer H, Huson SM, Lalloo F. Birth incidence and prevalence of tumor-prone syndromes: estimates from a UK family genetic register service. Am J Med Genet A 2010;152A(2):327-32.

40. Lammert M, Friedman JM, Kluwe L, Mautner VF. Prevalence of neurofibromatosis 1 in German children at elementary school enrollment. Arch Dermatol 2005;141(1):71-4.

41. Uusitalo E, Leppavirta J, Koffert A, Suominen S, Vahtera J, Vahlberg T, Poyhonen M, Peltonen J, Peltonen S. Incidence and mortality of neurofibromatosis: a total population study in Finland. J Invest Dermatol 2015;135(3):904-06.

42. Westdorp H, Kolders S, Hoogerbrugge N, de Vries IJM, Jongmans MCJ, Schreibelt G. Immunotherapy holds the key to cancer treatment and prevention in constitutional mismatch repair deficiency (CMMRD) syndrome. Cancer Lett 2017;403:159-64.

43. Leenders E, Westdorp H, Bruggemann RJ, Loeffen J, Kratz C, Burn J, Hoogerbrugge N, Jongmans MCJ. Cancer prevention by aspirin in children with Constitutional Mismatch Repair Deficiency (CMMRD). Eur J Hum Genet 2018.

44. Durno CA, Aronson M, Tabori U, Malkin D, Gallinger S, Chan HS. Oncologic surveillance for subjects with biallelic mismatch repair gene mutations: 10 year follow-up of a kindred. Pediatr Blood Cancer 2012;59(4):652-6.

45. Ramchander NC, Ryan NA, Crosbie EJ, Evans DG. Homozygous germ-line mutation of the PMS2 mismatch repair gene: a unique case report of constitutional mismatch repair deficiency (CMMRD). BMC Med Genet 2017;18(1):40.

46. Thompson BA, Spurdle AB, Plazzer JP, Greenblatt MS, Akagi K, Al-Mulla F, Bapat B, Bernstein I, Capella G, den Dunnen JT, du Sart D, Fabre A, Farrell MP, Farrington SM, Frayling IM, Frebourg T, Goldgar DE, Heinen CD, Holinski-Feder E, Kohonen-Corish M, Robinson KL, Leung SY, Martins A, Moller P, Morak M, Nystrom M, Peltomaki P, Pineda M, Qi M, Ramesar R, 
Rasmussen LJ, Royer-Pokora B, Scott RJ, Sijmons R, Tavtigian SV, Tops CM, Weber T, Wijnen J, Woods MO, Macrae F, Genuardi M. Application of a 5-tiered scheme for standardized classification of 2,360 unique mismatch repair gene variants in the InSiGHT locus-specific database. Nat Genet 2014;46(2):107-15.

47. Møller P, Seppälä TT, Bernstein I, Holinski-Feder E, Sala P, Evans DG, Lindblom A, Macrae F, Blanco I, Sijmons RH, Jeffries J, Vasen HFA, Burn J, Nakken S, Hovig E, Rodland EA, Tharmaratnam K, de Vos Tot Nederveen Cappel WH, Hill J, Wijnen JT, Jenkins MA, Green K, Lalloo F, Sunde L, Mints M, Bertario L, Pineda M, Navarro M, Morak M, Renkonen-Sinisalo L, Valentin MD, Frayling IM, Plazzer JP, Pylvanainen K, Genuardi M, Mecklin JP, Moeslein G, Sampson JR, Capella G, Mallorca G. Cancer risk and survival in path_MMR carriers by gene and gender up to 75 years of age: a report from the Prospective Lynch Syndrome Database. Gut 2018;67(7):1306-16.

48. Vasen HF, Blanco I, Aktan-Collan K, Gopie JP, Alonso A, Aretz S, Bernstein I, Bertario L, Burn J, Capella G, Colas C, Engel C, Frayling IM, Genuardi M, Heinimann K, Hes FJ, Hodgson SV, Karagiannis JA, Lalloo F, Lindblom A, Mecklin JP, Moller P, Myrhoj T, Nagengast FM, Parc Y, Ponz de Leon M, Renkonen-Sinisalo L, Sampson JR, Stormorken A, Sijmons RH, Tejpar S, Thomas HJ, Rahner N, Wijnen JT, Jarvinen HJ, Moslein G, Mallorca g. Revised guidelines for the clinical management of Lynch syndrome (HNPCC): recommendations by a group of European experts. Gut 2013;62(6):812-23.

49. European Society of Human Genetics. Genetic testing in asymptomatic minors: Recommendations of the European Society of Human Genetics. Eur J Hum Genet 2009;17(6):720-1.

50. Bruwer Z, Algar U, Vorster A, Fieggen K, Davidson A, Goldberg P, Wainwright H, Ramesar R. Predictive genetic testing in children: constitutional mismatch repair deficiency cancer predisposing syndrome. J Genet Couns 2014;23(2):147-55.

51. Barrow E, Hill J, Evans DG. Cancer risk in Lynch Syndrome. Fam Cancer 2013;12(2):229-40.

52. ten Broeke SW, Brohet RM, Tops CM, van der Klift HM, Velthuizen ME, Bernstein I, Capella Munar G, Gomez Garcia E, Hoogerbrugge N, Letteboer TG, Menko FH, Lindblom A, Mensenkamp AR, Moller P, van Os TA, Rahner N, Redeker BJ, Sijmons RH, Spruijt L, Suerink M, Vos YJ, Wagner A, Hes FJ, Vasen HF, Nielsen M, Wijnen JT. Lynch syndrome caused by germline PMS2 mutations: delineating the cancer risk. J Clin Oncol 2015;33(4):319-25.

53. Gallinger S, Aronson M, Shayan K, Ratcliffe EM, Gerstle JT, Parkin PC, Rothenmund H, Croitoru M, Baumann E, Durie PR, Weksberg R, Pollett A, Riddell RH, Ngan BY, Cutz E, Lagarde AE, Chan HS. Gastrointestinal cancers and neurofibromatosis type 1 features in children with a germline homozygous MLH1 mutation. Gastroenterology 2004;126(2):576-85.

54. Yeung JT, Pollack IF, Shah S, Jaffe R, Nikiforova M, Jakacki RI. Optic pathway glioma as part of a constitutional mismatch-repair deficiency syndrome in a patient meeting the criteria for neurofibromatosis type 1. Pediatr Blood Cancer 2013;60(1):137-9.

55. Tesch VK, H IJ, Raicht A, Rueda D, Dominguez-Pinilla N, Allende LM, Colas C, Rosenbaum T, llencikova D, Baris HN, Nathrath MHM, Suerink M, Januszkiewicz-Lewandowska D, Ragab I, Azizi AA, Wenzel SS, Zschocke J, Schwinger W, Kloor M, Blattmann C, Brugieres L, van der Burg M, Wimmer K, Seidel MG. No Overt Clinical Immunodeficiency Despite Immune Biological Abnormalities in Patients With Constitutional Mismatch Repair Deficiency. Front Immunol 2018;9:1506.

56. Shiran SI, Ben-Sira L, Elhasid R, Roth J, Tabori U, Yalon M, Constantini S, Dvir R. Multiple Brain Developmental Venous Anomalies as a Marker for Constitutional Mismatch Repair Deficiency Syndrome. AJNR Am J Neuroradiol 2018; In press.

57. Overall ADJ. Recessive disorders: Consanguinity and population substructure in British Pakistani communities. In: Koven VT, ed. Population Genetics Research Progress: Nova Science Publishers, Inc., 2008:89. 
58. Wimmer K, Callens T, Wernstedt A, Messiaen L. The NF1 gene contains hotspots for L1 endonuclease-dependent de novo insertion. PLoS Genet 2011;7(11):e1002371.

59. Zatkova A, Messiaen L, Vandenbroucke I, Wieser R, Fonatsch C, Krainer AR, Wimmer K. Disruption of exonic splicing enhancer elements is the principal cause of exon skipping associated with seven nonsense or missense alleles of NF1. Hum Mutat 2004;24(6):491-501.

60. Messiaen LM, Wimmer K. Pitfalls of automated comparative sequence analysis as a single platform for routine clinical testing for NF1. J Med Genet 2005;42(5):e25.

61. Maertens O, De Schepper S, Vandesompele J, Brems H, Heyns I, Janssens S, Speleman F, Legius E, Messiaen L. Molecular dissection of isolated disease features in mosaic neurofibromatosis type 1. Am J Hum Genet 2007;81(2):243-51.

62. De Vos M, Hayward BE, Picton S, Sheridan E, Bonthron DT. Novel PMS2 pseudogenes can conceal recessive mutations causing a distinctive childhood cancer syndrome. Am J Hum Genet 2004;74(5):954-64.

63. Ganster C, Wernstedt A, Kehrer-Sawatzki H, Messiaen L, Schmidt K, Rahner N, Heinimann K, Fonatsch C, Zschocke J, Wimmer K. Functional PMS2 hybrid alleles containing a pseudogenespecific missense variant trace back to a single ancient intrachromosomal recombination event. Hum Mutat 2010;31(5):552-60.

64. Hayward BE, De Vos M, Valleley EM, Charlton RS, Taylor GR, Sheridan E, Bonthron DT. Extensive gene conversion at the PMS2 DNA mismatch repair locus. Hum mutat 2007;28(5):424-30.

65. van der Klift HM, Tops CM, Bik EC, Boogaard MW, Borgstein AM, Hansson KB, Ausems MG, Gomez Garcia E, Green A, Hes FJ, Izatt L, van Hest LP, Alonso AM, Vriends AH, Wagner A, van Zelst-Stams WA, Vasen HF, Morreau H, Devilee P, Wijnen JT. Quantification of sequence exchange events between PMS2 and PMS2CL provides a basis for improved mutation scanning of Lynch syndrome patients. Hum mutat 2010;31(5):578-87.

66. Clendenning M, Hampel H, LaJeunesse J, Lindblom A, Lockman J, Nilbert M, Senter L, Sotamaa K, de la Chapelle A. Long-range PCR facilitates the identification of PMS2-specific mutations. Hum Mutat 2006;27(5):490-5.

67. Etzler J, Peyrl A, Zatkova A, Schildhaus HU, Ficek A, Merkelbach-Bruse S, Kratz CP, Attarbaschi A, Hainfellner JA, Yao S, Messiaen L, Slavc I, Wimmer K. RNA-based mutation analysis identifies an unusual MSH6 splicing defect and circumvents PMS2 pseudogene interference. Hum mutat 2008;29(2):299-305.

68. van der Klift HM, Mensenkamp AR, Drost M, Bik EC, Vos YJ, Gille HJ, Redeker BE, Tiersma Y, Zonneveld JB, Garcia EG, Letteboer TG, Olderode-Berends MJ, van Hest LP, van Os TA, Verhoef S, Wagner A, van Asperen CJ, Ten Broeke SW, Hes FJ, de Wind N, Nielsen M, Devilee P, Ligtenberg MJ, Wijnen JT, Tops CM. Comprehensive Mutation Analysis of PMS2 in a Large Cohort of Probands Suspected of Lynch Syndrome or Constitutional Mismatch Repair Deficiency Syndrome. Hum mutat 2016;37(11):1162-79.

69. Vaughn CP, Hart KJ, Samowitz WS, Swensen JJ. Avoidance of pseudogene interference in the detection of 3' deletions in PMS2. Hum mutat 2011;32(9):1063-71.

70. Vaughn CP, Robles J, Swensen JJ, Miller CE, Lyon E, Mao R, Bayrak-Toydemir P, Samowitz WS. Clinical analysis of PMS2: mutation detection and avoidance of pseudogenes. Hum mutat 2010;31(5):588-93.

71. Wernstedt A, Valtorta E, Armelao F, Togni R, Girlando S, Baudis M, Heinimann K, Messiaen L, Staehli N, Zschocke J, Marra G, Wimmer K. Improved multiplex ligation-dependent probe amplification analysis identifies a deleterious PMS2 allele generated by recombination with crossover between PMS2 and PMS2CL. Genes, Chromosomes Cancer 2012;51(9):819-31.

72. Wimmer K, Wernstedt A. PMS2 gene mutational analysis: direct cDNA sequencing to circumvent pseudogene interference. Methods Mol Biol 2014;1167:289-302.

73. Andersen SD, Liberti SE, Lutzen A, Drost M, Bernstein I, Nilbert M, Dominguez M, Nystrom $M$, Hansen TV, Christoffersen JW, Jager AC, de Wind N, Nielsen FC, Torring PM, Rasmussen L. 
Functional characterization of MLH1 missense variants identified in Lynch syndrome patients. Hum mutat 2012;33(12):1647-55.

74. Drost $\mathrm{M}$, Koppejan $\mathrm{H}$, de Wind $\mathrm{N}$. Inactivation of DNA mismatch repair by variants of uncertain significance in the PMS2 gene. Hum mutat 2013;34(11):1477-80.

75. Drost M, Zonneveld J, van Dijk L, Morreau H, Tops CM, Vasen HF, Wijnen JT, de Wind N. A cellfree assay for the functional analysis of variants of the mismatch repair protein MLH1. Hum mutat 2010;31(3):247-53.

76. Drost M, Zonneveld JB, van Hees S, Rasmussen LJ, Hofstra RM, de Wind N. A rapid and cell-free assay to test the activity of lynch syndrome-associated MSH2 and MSH6 missense variants. Hum mutat 2012;33(3):488-94.

77. Kansikas M, Kariola R, Nystrom M. Verification of the three-step model in assessing the pathogenicity of mismatch repair gene variants. Hum mutat 2011;32(1):107-15.

78. Ollila S, Sarantaus L, Kariola R, Chan P, Hampel H, Holinski-Feder E, Macrae F, Kohonen-Corish M, Gerdes AM, Peltomaki P, Mangold E, de la Chapelle A, Greenblatt M, Nystrom M. Pathogenicity of $\mathrm{MSH} 2$ missense mutations is typically associated with impaired repair capability of the mutated protein. Gastroenterology 2006;131(5):1408-17.

79. Rasmussen LJ, Heinen CD, Royer-Pokora B, Drost M, Tavtigian S, Hofstra RM, de Wind N. Pathological assessment of mismatch repair gene variants in Lynch syndrome: past, present, and future. Hum mutat 2012;33(12):1617-25.

80. Boland CR, Shike M. Report from the Jerusalem workshop on Lynch syndrome-hereditary nonpolyposis colorectal cancer. Gastroenterology 2010;138(7):2197 e1-7.

81. Ingham D, Diggle CP, Berry I, Bristow CA, Hayward BE, Rahman N, Markham AF, Sheridan EG, Bonthron DT, Carr IM. Simple detection of germline microsatellite instability for diagnosis of constitutional mismatch repair cancer syndrome. Hum Mutat 2013;34(6):847-52.

82. How-Kit A, Daunay A, Buhard O, Meiller C, Sahbatou M, Collura A, Duval A, Deleuze JF. Major improvement in the detection of microsatellite instability in colorectal cancer using HSP110 T17 E-ice-COLD-PCR. Hum mutat 2018;39(3):441-53.

83. Bodo S, Colas C, Buhard O, Collura A, Tinat J, Lavoine N, Guilloux A, Chalastanis A, Lafitte P, Coulet F, Buisine MP, llencikova D, Ruiz-Ponte C, Kinzel M, Grandjouan S, Brems H, Lejeune S, Blanche H, Wang Q, Caron O, Cabaret O, Svrcek M, Vidaud D, Parfait B, Verloes A, Knappe UJ, Soubrier F, Mortemousque I, Leis A, Auclair-Perrossier J, Frebourg T, Flejou JF, EntzWerle N, Leclerc J, Malka D, Cohen-Haguenauer O, Goldberg Y, Gerdes AM, Fedhila F, Mathieu-Dramard M, Hamelin R, Wafaa B, Gauthier-Villars M, Bourdeaut F, Sheridan E, Vasen H, Brugieres L, Wimmer K, Muleris M, Duval A, European Consortium "Care for C. Diagnosis of Constitutional Mismatch Repair-Deficiency Syndrome Based on Microsatellite Instability and Lymphocyte Tolerance to Methylating Agents. Gastroenterology 2015;149(4):1017-29 e3.

84. Taeubner J, Wimmer K, Muleris M, Lascols O, Colas C, Fauth C, Brozou T, Felsberg J, Riemer J, Gombert M, Ginzel S, Hoell JI, Borkhardt A, Kuhlen M. Diagnostic challenges in a child with early onset desmoplastic medulloblastoma and homozygous variants in MSH2 and MSH6. Eur J Hum Genet 2018;26(3):440-44.

85. Haraldsdottir S, Rafnar T, Frankel WL, Einarsdottir S, Sigurdsson A, Hampel H, Snaebjornsson $P$, Masson G, Weng D, Arngrimsson R, Kehr B, Yilmaz A, Haraldsson S, Sulem P, Stefansson T, Shields PG, Sigurdsson F, Bekaii-Saab T, Moller PH, Steinarsdottir M, Alexiusdottir K, Hitchins M, Pritchard CC, de la Chapelle A, Jonasson JG, Goldberg RM, Stefansson K. Comprehensive population-wide analysis of Lynch syndrome in Iceland reveals founder mutations in MSH6 and PMS2. Nat Commun 2017;8:14755.

86. Okkels H, Lindorff-Larsen K, Thorlasius-Ussing O, Vyberg M, Lindebjerg J, Sunde L, Bernstein I, Klarskov L, Holck S, Krarup HB. MSH6 mutations are frequent in hereditary nonpolyposis colorectal cancer families with normal pMSH6 expression as detected by immunohistochemistry. Appl Immunohistochem Mol Morphol 2012;20(5):470-7. 
